Cahiers $d u$ MONDE RUSSE

\section{Cahiers du monde russe}

Russie - Empire russe - Union soviétique et États indépendants

$49 / 4 \mid 2008$

Destins individuels et terreur. Jeunesse dans la société post-stalinienne

\title{
Nicolas Werth, L'ivrogne et la marchande de fleurs
}

\section{Andrea Graziosi}

\section{(2) OpenEdition}

1 Journals

\section{Electronic version}

URL: https://journals.openedition.org/monderusse/6942

DOI: $10.4000 /$ monderusse. 6942

ISSN: $1777-5388$

\section{Publisher}

Éditions de l'EHESS

\section{Printed version}

Date of publication: 28 December 2008

Number of pages: $748-756$

ISBN: 978-2-7132-2197-2

ISSN: $1252-6576$

\section{Electronic reference}

Andrea Graziosi, "Nicolas Werth, L'ivrogne et la marchande de fleurs", Cahiers du monde russe [Online], 49/4 | 2008, Online since 23 December 2009, connection on 02 September 2022. URL: http://

journals.openedition.org/monderusse/6942 ; DOI: https://doi.org/10.4000/monderusse.6942

This text was automatically generated on 2 September 2022

All rights reserved 


\title{
Nicolas Werth, L'ivrogne et la marchande de fleurs
}

\author{
Andrea Graziosi
}

\section{REFERENCES}

Nicolas WERTH, L'ivrogne et la marchande de fleurs. Autopsie d'un meurtre de masse, 1937-1938. Paris : Taillandier, 2009, $335 \mathrm{p}$.

1 This is an intelligent, humane and rich book, one from which even the specialist has much to learn. Werth carefully gathered together the exceptional documents unearthed after 1991 by Memorial researchers, to whom the book is properly dedicated, and ably combined them with those published by scholars such as Khaustov ${ }^{1}$, as well as with what he himself discovered and learnt over the years, to produce the best book we have today on the Great Terror.

2 Given the extraordinary quality of the documents in question, capable of altering our perception and interpretation of the first half of the twentieth century, Werth rightly quotes from them at length, and reports some of them in full, following the model set by Oleg Khlevniuk ${ }^{2}$. From this point of view, the book is but the natural evolution, and the fruit, of the formidable season which renewed our knowledge of Soviet history through the publication of hundreds of valuable documentary collections (sborniki dokumentov), whose treasures often still wait for their historians.

Since the very first pages, devoted to the case of a drunkard, Werth focuses on the "little people"targeted by mass operations, noting that the great Moscow show trials were also "événements-écrans"(16). Far from what has been believed for a long time, the Great Terrorwas in fact:"d'abord et avant tout une vaste entreprise d'ingénierie et de 'purification' sociale visant à éradiquer, par des opérations secrètes, décidées et planifiées au plus haut niveau [...], tous les éléments 'socialement nuisibles' et 'ethniquement suspects"'(17). More than $90 \%$ of the 1937-1938 victims were exterminated locally following the "kulak" line (the 00447 decree) or one of the many national ones 
(Polish, German, Latvian, Finnish, etc.). The "high" purge followed instead its own course: arrested leaders, approximately 50,000, were generally brought to Moscow where they were judged by the Military Collegium of the Supreme Court, and executed after Stalin and his minions had signed the lists with their names, as required by nomenklatura rules.

Werth thus immediately raises the question of the relations between "purges des élites et opérations de masse," the title he gave to his first chapter, to which I shall return after discussing chapters 2-4, which form the heart of the book.

5 Chapter 2, "Le processus de prise de décision: quotas, lignes et dépassement," is excellent. It begins with the Politburo directive of July 2, 1937, which Ezhov circulated among regional and republican NKVD leaders, requesting that they send to Moscow within five days data on how many anti-Soviet elements they had in their files, divided into two categories on the basis of the danger they posed. The extremely complex and important question of the preventive filing of potential enemies in the USSR is thus raised. Filekeeping started soon after the revolution, and the institutions involved were many. The political police and the Party control commission, as far as former oppositionists were concerned, kept the most important ones, but local soviets, the militia (and especially, after 1933, its passport offices), employment bureaus, etc., had their own.

The 15 or so categories under surveillance in 1937 were similar to those of 1922 (see my L'Urss di Lenin e Stalin, Bologna, 2007, 180-81).The special colonists deported in the 1930-1933 kulak operations were the most important new entry, followed by exiled people of every kind, byvshie, former leaders of, and participants in, peasant insurrections, members of the clergy of all religions, sektanty, former members of political parties, especially socialist ones, party oppositionists, all those sentenced on the basis of Article 58 , and recidivists, political immigrants and foreign citizens in general, Soviet citizens who had lived abroad or had or maintained contacts with foreign countries, and those of "untrustworthy" national descent (Polish, German, Baltic, Romanian, Finnish etc.), especially if they worked in armament-related factories. We do not know how many people these categories included, but the grand total was certainly well over one million.

7 Data started to flow in on July 8, and in the following days the Politburo adopted resolutions detailing regional and republican quotas, and establishing the troika which was to "judge" the arrested. On July 16 the NKVD convened in Moscow a crucial meeting to prepare such an exceptionally importantoperation. Orders were top-secret, and only approximately 200 Republican and regional Party and NKVD leaders saw their written version. Subordinates, apparently including district leaders, acted on oral instructions, a proof not only of their blind obedience, but also of their basic support for the decision to cleanse "once and for all" the country of its enemies. Werth quotes an extraordinary document of the second half of July, in which Mironov, head of Western Siberia's NKVD, thus addressed his subordinates, ordering them to set up district and area operational groups, and to choose suitable places for executions and burials:

Jusqu'à ce qu'on ait terminé cette opération, sachez que celle-ci est absolument secrète, un secret d'État. Quand je vous présenterai le Plan attribué à notre région, les chiffres que vous entendrez, vous devrez les faire disparaître de votre tête. Ceux qui ne parviendront pas à extirper ces chiffres de leur tête, ils devront se faire violence, et les chasser d'une manière ou d'une autre, car la moindre mention de ces chiffres vous conduirait sur-le-champ devant un tribunal militaire [...]. (86)

8 Ezhov signed NKVD decree 00447 on July 30, and the Politburo approved it on the following day. Operations thus started at the beginning of August. In 10 days 100,000 had already been arrested, and by September 1, executions already passed the 30,000 mark. In 
August, Moscow explained what kind of people had to be sentenced first: side by side with former political militants and participants in peasant insurrections we find recidivists and people without a stable residence or occupation, often the victims of the cruel social uprooting caused by Stalin's revolution from above. In any case, contrary to what we thought on the basis of survivors' memoirs, in most cases only a few weeks separated arrest from sentence.

Werth convincingly reconstructs the combination of pressure from above and initiative from below which in the following months led to successive extensions of decree 00447's deadline. In yet another extraordinary document, we see Maltsev, head of Tomsk NKVD, spurring his men to force the rhythm, "because our Urals colleagues are well ahead of us" (108). And we read single Politburo decisions, like that of October 10, 1937, which "gave" the kulak operation yet another 120,000 new victims. All in all, the number of those sentenced to camps thus doubled, and executions were multiplied fivefold.

10 As Werth rightly remarks, following Jansen's and Petrov's Stalin's Loyal Executioner: People's Commissar Nikolai Ezhov, 1895-1940 (Stanford, 2002), we do not know the limits of Ezhov's autonomy in assigning extra quotas. According to documents, the Politburo gave permission for 184,750 new victims, and Ezhov personally for about 300,000. Yet we also know that in those months, Ezhov spent hundreds of hours in Stalin's office, and we have no records of their conversations. In any case, Stalin carefully followed the operations and he did set the tone, e.g. with his famous toast on the revolution's twentieth anniversary, when he drank to the extermination of all state enemies, including their family and lineage (rod, 141).

11 On January 14, 1938, Stalin personally extended the 00447 operation indefinitely, and four days later he gave detailed instructions on the "lines" which were to be followed in a note to Ezhov which opens striking perspectives on his way of thinking and acting ${ }^{3}$ :

La ligne SR (de gauche et de droite, prise ensemble) n'est toujours pas dévidée... Est-ce que le NKVD a bien un fichier des SR (des «ex») infiltrés dans l'armée? Je voudrais bien recevoir ce fichier et rapidement. Est-ce que le NKVD a un fichier des ex-SR hors de l'armée (dans les administrations) ? Je l'attends pour dans deuxtrois semaines... Il faut agir plus rapidement et efficacement.(109)

12 A month later, Stalin accorded Ukraine the largest extra quota ever granted to a "region." Werth reports the text of Ezhov's extraordinary speech to the Ukrainian NKVD leaders, in which-after praising file-building as an "indispensable preparatory work"he invited them to use the extra 30,000 victims well: "les 30000 c'est la crème [...] En un mot, il faut couper les têtes, écrémer, enlever la crème [...] Vous allez leur porter un tel coup qu'ils ne s'en relèveront jamais"(113), words almost identical to those Lenin uttered in 1922 when he ordered to use the famine to hit the Orthodox Church.

13 Not surprisingly, in such a climate local police officials vied with one another in "unearthing" huge conspiracies, and the combination of Marxism's semi-paranoid vision of history as the product of class struggle, the Bolsheviks' own obsession with plot theories, fed by the civil war, and Stalin's personal folly reached its acme.

14 In April 1938, decree 00447 was extended one more time, but only to border regions and what Werth rightly terms the "dump" (zones poubelles), where the regime had confined its enemies, and which thus needed extra "cleansing." For the last couple of months, however, "national operations" had become the terror's most important "line." Back on August 11, 1937, following yet another Politburo decision, Ezhov had signed decree 00485, directed against the "Polish military organization." It called for the arrest of all 
kinds of Polish residents and émigrés, including political ones, as well as of all the "most active elements" living in the Polish districts of the USSR. Two months later, after receiving a report on the mass arrests of both Polish citizens and Soviet citizens of Polish descent, Stalin mailed the NKVD chief yet another stunning note: "Cam. Iejov. Voilà qui est excellent! Continuez à creuser, à nettoyer et à éradiquer toute cette saleté polonaise. Liquidez-la complètement au nom des intérêts de l'URSS" (140).

The "Polish" decree was soon followed by those affecting other national groups. As Werth remarks, the major difference between them and decree 00447 was the lack of quotas, which resulted in a huge raise in the number of first-category victims, i.e. of executions.

Chapter 3, "La mise en œuvre des 'Opérations de masse", is also excellent, even though the harshness of the events it deals with makes at times for painful reading. Perpetrators and their methods are starkly portrayed. Werth notes that, contrary to the Khrushchevian legend, most NKVD leaders had entered the political police during the civil war, and as in the civil war, the mass of the approximately 25,000 civilian agents (less than one third of what they had been in 1921) only completed primary education. Thus the structure was that of 1918-1921, with a thin layer of old Bolsheviks commanding a corps of violence-prone ignorant individuals of very low social extraction, among whom there were not a few former common criminals. Again, as in the civil war, theirs was a cruel world, where crude ideology and devotion and fear of leaders lived side by side with alcoholism and mass stealing during searches and arrests.

The civil war's legacy is also attested by data, such as those concerning the 10,000 people executed by the Altai Gubcheka alone in 1920. The scale of those executions, subsequently repeated in Crimea, Tambov, the Northern Caucasus, etc., shows that the political police was a tool already honed for mass murder. As attested by the thousands of executions which ended the Georgian 1924 insurrection in blood or the 5,000 carried out by the Siberian GPU in 1930, this practice continued in following years. One is thus forced to conclude that the impressive table compiled by colonel Pavlov in 1953, on Khrushchev's order, on the people shot by the political police in Stalin's time-a table most historians regularly refer to-is unreliable, with the possible exception of 1937-38 (see below).

Such numbers, and their multiplication after July 1937, raise once more the question of the perpetrators' mentality and self-justifications. At the beginning, the announcement that the time of the final struggle against the revolutionary state's enemies had arrived may have even aroused some enthusiasm. Yet the documents show that the awareness that masses of innocents were being exterminated, and the repression of political police cadres, created not a few problems. Alcoholism exploded, and as a NKVD official wrote soon before his own arrest in 1938: "J'ai travaillé comme tout le monde à l'extermination des ennemis, mais jamais ne m'a quitté la pensée que je pouvais à tout moment être désarmé, arrêté et descendu dans une cave" (151) - a thought that was also on Khrushchev's mind. ${ }^{4}$

Werth also tries to analyze the ways in which contemporaries interpreted the events. Unfortunately the NKVD reports he uses are not so rich, but the feeling that "1920 was back" (179) must have been shared by many. Those reports could have been supplemented by memoirs such as F. Beck's and W. Godin's (two pseudonyms), ${ }^{5}$ which contains an interesting review of how arrested people tried to explain what was 
happening. In general, however, with no knowledge of the secret decrees it was impossible fully to understand.

The hypothesis that in the fall of 1937 mass operations went partially out of control-but never in the sense that Stalin could not stop them at will-is convincing, and as convincing is the explanation that Werth provides for it. Three local factors were at play, namely the needs to inflate numbers, to produce group cases and unmask the inobasa (the milieus that foreign powers could use). These needs were however fed by Moscow. As the head of Sverdlovsk's NKVD told his subordinates in September 1937, reporting orders from above: "Je ne veux plus d'affaires individuelles et de 'propagande antisoviétique,' il nous faut des affaires groupées, espionnage, diversion et terrorisme" (195).

In order to produce such results and the required numbers, especially after the original fileshad been exploited, new methods were devised. In Sverdlovsk, NKVD officers were divided, on the basis of their "talents" into two groups, the "intellectuals", charged with producing conspiracies and confessions, and the "breakers" (casseurs), who had to extract the needed signatures. Two models of confessions were put together, one for leading conspirators, and the other for their agents. The investigators filled them out, adding a few details of their own choosing concerning the nature of the sabotage or the espionage activities. Previous industrial or car accidents, technical mishaps, etc., were put to good use. Yet, Stalin's advice was sought even in such cases, as when Vyshinskii asked his permission to prosecute several managers for "sabotaging" Leningrad's trolleybuses, a request Stalin found the time to answer in detail, indicating also which article had to be used in the incrimination of people he had never heard of (211).

The pages that follow are terrible, but indispensable to understand the Great Terror's reality, and Werth's choice to publish a few frightful documents is fully justified. We read of people beheaded, strangled, or whose skulls were crushed with iron bars by drunken sadists who boasted to be leaders because they were capable "de couper la viande humaine comme du radis."

23 Werth opens Chapter 4, devoted to the victims, with Roginskii's and Petrov's critical assessment of Petrov's numbers, which should be revised upward by approximately 5-10\%, a significant percentage, but inferior to that which should be applied, for instance, to the 1930 or 1932 figures. All in all, 725-741,000 people were executed in less than 16 months, and another 150-200,000 died in camps (235): one adult citizen out of 200 was therefore executed, and one out of 100 arrested.

Werth then asks crucial questions relating to the geography of repression, and to the national and social belonging of the victims. Karelia, which was both a zone poubelle for deported people, and a border area whose inhabitants could be suspected of double loyalty, had the largest percentage of arrested people (3\% of its population). Then came Siberia, another great zone poubelle, with $1.8 \%$, followed by the Donbass, the German Volga Republic, Turkmenistan, and regions like Krasnodar and Sverdlovsk (from $1.2 \%$ to 1.6\%). Belorussia, Leningrad, and Moscow were "average," as was Ukraine, where accounts with Ukrainians had been settled in 1932-1933, and where many of the 1937-1938 victims were people of Polish or German descent. Some were shot for having spread "false information" about a "presumed famine." In other regions like Tatarstan, Iaroslav, Ivanovo, Riazan, etc., "only" $0.5 \%$ of the population fell victim to the Great Terror.

Out of a total of 636,000 Poles or Soviet citizens of Polish descent 118-123,000 were arrested, and $80 \%$ of those were shot. A "Pole" thus had 20 times as many chances to be repressed as a Russian. "Germans," "Finns," and "Letts" followed (quotation marks are 
needed because these were generally Soviet citizens). Werth does not address the Jewish question, but other scholars have claimed that urban, modernized Jews, especially those who had emigrated to large Russian cities, and later became a major target of Stalinist repression, apparently were not particularly hit by the Great Terror, perhaps also because they were not yet considered a "dangerous" nationality, ${ }^{6}$ but this hypothesis still expects confirmation.

As Werth persuasively argues, NKVD statistics on the victims' social origin and composition were heavily tampered with in order to prove that the "right" groups had been targeted. Figures concerning workers and kolkhozniki were thus conveniently reduced. Clerics of all religious denominations, and members of former socialist parties, socialist-revolutionaries in particular, were the hardest-hit groups. In December 1937, in a report to Stalin, Ezhov boasted that the Orthodox Church had been annihilated, and his claim was supported by the liquidation of approximately $90 \%$ of the clergy. Former socialist militants suffered a similar fate. Among special settlers, i.e. former "kulaks," the percentage of arrested people in some regions reached $20 \%$ of the adult male population, but on average it was around 10\%, nine times less than among former Mensheviks. Recidivists instead were singled out (up to 70\% of those arrested in 1937-1938 had been sentenced in the past, many of them for "common" crimes), as were employees of defense-related factories and institutions, people who had every imaginable kind of relations with foreign countries, and members of the still remaining independent social groups, such as charretiers and individual peasants.

Werth, however, also underlines the role of circumstances, like those that determined the arrest and execution of the old flower sellermentioned in the book's title.

Werth discusses the Great Terror's causes, and its possible interpretations, in the first chapter, devoted to elite purges and mass operations. Though always interesting, and marking progress in crucial areas, this chapter is not as convincing as the others. The purges of the élites are presented as the result of the combined pressure of two main fault lines within the Stalinist system, that between: "la logique stalinienne du 'clan,' despotique et policière, fondée sur le principe de l'allégeance, et la logique administrative d'un État industriel moderne"(27); and the other between Moscow and the periphery. But similar tensions, and even more intense ones, marked other dictatorships, and yet did not produce the mass torture and the extermination of the dictator's former companions and of hundreds of thousands of people in peace time. The Bolshevik mentality and Stalin's mind were thus crucial factors and the bloody traits assumed by personal relations within the élite in the USSR cannot be explained without understanding the despot's personality. It was within it that what Burckhardt called "ugly imperial madness" assumed particularly disturbing features, shown by letters such as the one Stalin sent Ezhov in October, 1937, while Iakovlev, the Narkomzem of collectivization, was under interrogation:

Ce qui m'intéresse, ce n'est pas l'activité passée de Iakovlev et de son épouse, mais leurs activités d'espionnage cette dernière année, et précisément au cours des derniers mois. Je voudrais bien savoir pourquoi ces deux salauds allaient chaque année à l'étranger. Faites leur cracher tout ce qu'ils essaient de nous cacher. (43)

The discussion of the combination between the need to eliminate the slag left by the building of socialism once that building was declared over in 1936, and that to prepare for war by eliminating all possible fifth columns, in precipitating the decision to "cleanse" the country, a combination already remarked by Bukharin in a famous letter to Stalin, is more convincing. As convincing is the reconstruction of the chronology of the "high" purge after the summer of 1936, which hit first, in connection with 
Stakhanovism, industrial specialists and Ordzhonikidze's NKTP, then regional and republican cliques, and finally-after the 1937 March plenum-top leaders, up to army ones in June. At the new plenum, held that very month, Ezhov denounced the existence of 13 major conspiracies led by former oppositionists. Thirty top leaders were arrested during the meeting, and in the following weeks most regional and republican élites were again purged, often after the celebration of local show trials.

The reconstruction of the backgroundof both the high purge and mass operations is not as satisfactory. As to the former, Werth rightly recalls Stalin's ominous speech at the Seventeenth Congress, yet crucial events such as the show trials of 1930-1931, the party crisis of 1932-1933, or the Enukidze affair of 1935 are not discussed. In a book devoted to mass operations, this is not a serious problem. However, the outline of the mass operations' "prehistory" we are presented with is not fully adequate either.

Quite rightly, after stating that Kirov's murder did not mark the beginning of the Terror, Werth lists the role of collectivization and dekulakization, the famine and the "cleansing" of cities that followed the introduction of passports at the end of 1932, and the campaign to cleanse western borders of potential enemies launched in March 1933. $\mathrm{He}$ also rightly underlines the creation of the already mentioned zones poubelles, and calls to our attention Stalin's obsession with the new "socially harmful elements" he himself had created, denounced at the January, 1933 plenum as a major danger for the regime, and exterminated in 1937-1938.

Often, however, these events are merely mentioned, Stalin's interpretations and analyses are not discussed, the role of theory and ideology-as in the repeated resort to Marx's "primitive accumulation" scheme, or in the use of "collective categories" and thus collective responsibility in the interpretation and manipulation of reality-is not given its due, and "precedents" like the extermination of besprizornye along railroad lines, which probably gave Stalin a "taste" of what could be done, are not recalled.

Above all, the civil war, though mentioned, is not adequately treated (not in terms of space, but in terms of its role), and the 1920s are simply not there. Yet categories and fileswere already in use, cities were "cleansed" of socially harmful elements, and during the war scare of 1927, Stalin repeatedly asked the GPU to resort to mass arrest to destroy espionage networks and "lay the foundations for the complete destruction with all revolutionary means" of counter-revolutionary organizations, in order "to strengthen the rear." He then also underlined the need to liquidate socially alien elements in the countryside and ordered the dissolution of some Polish districts in Belorussia, whose untrustworthy inhabitants were to be exiled.7 The final chapter, "Sortir de la Grande Terreur," clearly shows how strong Stalin's grip was on the mass operations' general course, if not on their local ones. The Great Terror ended as abruptly as it had begun, with a secret Politburo resolution of November 18, 1938 which criticized major defects and deformations in the NKVD's work, but praised what had been done "in order to liquidate enemies and cleanse the country" (291). Soon afterwards, Ezhov resigned, after admitting his mistakes in a pitiful letter in which he also defended his good intentions "before the Party CC and comrade Stalin in particular"(303). He was replaced with Beria, who had already been called to Moscow in August to take the place of Ezhov's arrested first deputy. In spite of his chekist past, Beria, whose talents Stalin had appreciated since at least 1932, was then the head of the Georgian party. His involvement in the mass operations thus mainly consisted in organizing their winding down, sanctioned in a decree he signed on November 26. Ezhov himself was arrested in April and accused to be 
an agent of four different foreign powers, to have plotted to kill Stalin, Molotov and Beria and of sodomy. Contrary to other important leaders, including Iagoda, his predecessor, he did not even get the "honor" of a show trial (Stalin considered him a depraved nullity) and was executed at the beginning of 1940. Apparently, his last words were for his master: "Dites à Staline que je meurs avec Son nom sur mes lèvres" (311). According to Werth, Stalin stopped the Great Terror because he realized that it was pushing the country toward collapse and disorder, attested among other things by the successful escapes of important NKVD leaders, such as Liushkov and Orlov, and because he was aware that war was fast approaching, and stability was thus needed. These must have indeed been important considerations, yet the Terror was perhaps stopped because, and after, it had achieved its aims.

Werth gave us a very important book, one which considerably furthers our knowledge of a most important historical event. The documents he uses, and the interpretations he can thus soundly put forward, confirm, and deepen, Khlevniuk's and Petrov's and Jansen's work. As all important books do, his too raises new problems and opens new lines of investigations, regarding for example the role of ideology, mentalities and personality in the Great Terror. And it leaves us pondering over the judgment we passed over an entire historical period. In the light of what Werth tells us, the comparison of the ferocious new European states acquires yet new dimensions, especially as far as the 1930s are concerned.

\section{NOTES}

1. Vladimir N. Khaustov, Lubianka: Stalin i glavnoe upravlenie gosbezopasnosti NKVD, 1937-1938, M.: Meždunarodnyj fond Demokratija, 2004.

2. See his The History of the GULag: From Collectivization to the Great Terror, New Haven-London: Yale University Press, 2004.

3. The note, by the way, is very similar to those he had sent to the OGPU in 1930; see O.V. Khlevniuk et al., eds., Pis'ma I.V. Stalina V.M. Molotovu 1925-1936 gg., M.: Rossija molodaja, 1995, p. 187.

4. William Taubman et al., eds., Nikita Khrushchev, New Haven-London: Yale University Press, 2000, p. 25.

5. Frederick Beck, W. Godin, Russian Purge and the Extraction of Confession, New York-London: Hurst \& Blackett, 1951.

6. Yuri Slezkine, The Jewish Century, Princeton: Princeton University Press, 2004.

7. Graziosi, L'Urss di Lenin e Stalin, 226-227. 